\title{
TrkA, But Not TrkC, Receptors Are Essential for Survival of Sympathetic Neurons In Vivo
}

\author{
Anne M. Fagan, ${ }^{1}$ Hong Zhang, ${ }^{2}$ Story Landis, ${ }^{2}$ Richard J. Smeyne, ${ }^{1}$ Inmaculada Silos-Santiago, ${ }^{1}$ and \\ Mariano Barbacid1 \\ ${ }^{1}$ Department of Molecular Oncology, Bristol-Myers Squibb Pharmaceutical Research Institute, Princeton, New Jersey \\ 08543, and 2Department of Neuroscience, Case Western Reserve University, Cleveland, Ohio 44195
}

\begin{abstract}
Neurotrophins and their signaling receptors, the Trk family of protein tyrosine kinases, play a major role in the development of the mammalian nervous system. To determine the precise stages that require Trk receptor signaling during development of the sympathetic system, we have analyzed the superior cervical ganglion (SCG) of embryonic and postnatal mice defective for each of the known Trk receptors. Transcripts encoding TrkC are detected in early sympathetic development, before the coalescence of the SCG. trkA expression appears at E13.5, becoming robust from E15.5 onward. In contrast, trkC expression decreases significantly after E15.5 and remains detectable only in a small subpopulation of cells. No significant trkB expression could be detected in the SCG at any developmental stage. Ablation of TrkA receptors does not affect neurogenesis, expression of neuronal markers, or initial axonal growth. How-
\end{abstract}

ever, these receptors are absolutely necessary for the survival of sympathetic neurons after E15.5 and for proper innervation of their distal targets. In contrast, mice defective for either TrkC or TrkB tyrosine kinase receptors do not display detectable defects in their SCGs. These results illustrate the differential roles of the Trk family of receptors during SCG development and define a critical role for TrkA signaling in the survival, but not differentiation, of SCG neurons. Moreover, these observations raise the possibility that at least some SCG neurons become neurotrophin-dependent before complete target innervation.

Key words: Trk receptors; neurotrophins; superior cervical ganglion; sympathetic neurons; neuronal survival; knockout mice
Neurotrophins are trophic factors necessary for the development of the vertebrate nervous system. These molecules are abundantly expressed in neural regions during embryonic development (Ernfors et al., 1992; Schecterson and Bothwell, 1992; Elkabes et al., 1994) and are likely to act by promoting the differentiation and/or survival of developing neurons (for review, see Barde, 1989; Korsching, 1993; Snider, 1994). In vitro studies have shown that early in development, neuronal survival is neurotrophinindependent. However, neurons become neurotrophin-dependent at later developmental stages (Coughlin and Collins, 1985; Ernsberger et al., 1989; Wyatt and Davies, 1993), often concomitant with the timing of target innervation (Vogel and Davies, 1991).

Neurotrophins exert their trophic actions by interacting with two classes of cell surface receptors. The Trk family of tyrosine protein kinase receptors are the primary mediators of neurotrophin signaling and provide functional specificity (for review, see Barbacid, 1994). For instance, whereas the TrkA receptor primarily recognizes nerve growth factor (NGF), TrkB mediates signaling of brain-derived neurotrophic factor (BDNF) and neurotrophin-4/5 (NT-4/5). TrkC receptors specifically interact with NT-3, a neurotrophin that can also activate TrkA and TrkB receptors under certain conditions (Bar-

Received April 22, 1996; revised July 16, 1996; accepted July 18, 1996.

This work was supported in part by National Institutes of Health Grant HD 25681 to S.C.L. We thank M. Garber, A. Lewin, L. Long, C. Marks, J. D. Wallace, and J. Wolf for their excellent technical assistance.

Correspondence should be addressed to Mariano Barbacid, Bristol-Myers Squibb Pharmaceutical Research Institute, P.O. Box 4000, Princeton, NJ 08543-4000.

Dr. Fagan's present address: Department of Neurology, Washington University School of Medicine, St. Louis, MO 63110.

Dr. Smeyne's present address: St. Jude Children's Research Hospital, Memphis, TN 38101.

Copyright (@) 1996 Society for Neuroscience $0270-6474 / 96 / 166208-11 \$ 05.00 / 0$ bacid, 1994). Each of the neurotrophins also binds with low affinity to another receptor, p75, a member of the TNF receptor family (Chao, 1994). The role of $\mathrm{p} 75$ in mediating neurotrophin function is still not fully resolved (Chao, 1994).

Recently, mice carrying targeted mutations in the genes encoding each of the known neurotrophins and their cognate receptors have been generated (Barbacid, 1994; Snider, 1994). These animals provide unique experimental tools with which to explore the role of trophic factor signaling during development of the nervous system. One of the most amenable systems to study neuronal development is the superior cervical ganglion (SCG), a major component of the mammalian sympathetic system. The SCG has been well characterized anatomically and functionally. Unlike sensory ganglia, the SCG contains primarily one class of neurons, principal sympathetic neurons. Early in development, sympathetic neurons and their precursors respond in vitro to NT-3 (Birren et al., 1993; DiCicco-Bloom et al., 1993). However, during late gestation they become dependent on NGF for survival, both in vitro (Levi-Montalcini and Angeletti, 1966; Chun and Patterson, 1977) and in vivo (Levi-Montalcini and Booker, 1960; Gorin and Johnson, 1980). The critical role of the NGF/TrkA signaling pathway in sympathetic development in vivo has been illustrated recently. Ablation of genes encoding either NGF (Crowley et al., 1994) or its signaling receptor TrkA (Smeyne et al., 1994) results in the virtual absence of SCG neurons by the first postnatal week. NT-3 null mice also exhibit a sympathetic defect. These mice have $\sim 50 \%$ fewer SCG neurons (Ernfors et al., 1994; Fariñas et al., 1994), consistent with the observation that NT-3 promotes the survival of sympathetic neuroblasts in culture (Birren et al., 1993; DiCicco-Bloom et al., 1993; Verdi and Anderson, 1994). 
In this study, we have examined the role of neurotrophin signaling during development of the mammalian sympathetic system by analyzing the SCG of mice lacking functional TrkA, TrkB and TrkC receptors. We report that TrkB and TrkC receptors are not required for normal sympathetic development in vivo. TrkA receptors are not necessary for the proliferation of SCG neuronal precursors or for their subsequent postmitotic differentiation into sympathetic neurons. However, these receptors are absolutely required for sympathetic neuron survival during late embryogenesis and early postnatal development. TrkA-deficient sympathetic neurons do not reach some of their distal targets, suggesting that these neurons become trophic factor-dependent before complete target innervation.

\section{MATERIALS AND METHODS}

Tissue processing. Mice were analyzed at embryonic day 11.5 (E11.5), E13.5, E15.5, E17.5, postnatal day 0 (P0), P5, P9, and P16. Embryos were obtained via Caesarean section from timed matings of $t r k \mathrm{~A}^{+/-}$(Smeyne et al., 1994), $\operatorname{trkC}^{+/-}$(Klein et al., 1994), or $\operatorname{trkB}^{+/-}$(Klein et al., 1993) heterozygous mice and fixed in $4 \%$ paraformaldehyde in $0.1 \mathrm{M}$ PBS. Animals younger than E15.5 were fixed via immersion. All others were perfused transcardially and fixed overnight in the same fixative. Heads or dissected SCGs were either embedded in paraffin or cryoprotected in $30 \%$ sucrose in PBS

Histological analysis. Paraffin sections $(5 \mu \mathrm{m})$ through the SCGs of wild-type animals and mutant animals at each developmental time point were stained with $0.2 \%$ cresyl violet and used for neuronal counts. Neuron numbers were determined by counting neuronal profiles exhibiting a visible nucleus and nucleolus in every fifth section. Raw counts were then corrected with a multiplication factor using section thickness and the average nuclear diameter. Because values of wild-type mice often vary between animals from different litters at a given developmental age, values derived from mutant mice were always compared (Student's $t$ tests) with their own wild-type littermates. The total number of mitotic figures and of pyknotic nuclei was also calculated at each developmental time point.

Semithin sectioning and electron microscopy. Postnatal (P1 and P5) trkA $\mathrm{A}^{-1-}$ animals and normal littermate controls were transcardially perfused with $4 \%$ paraformaldehyde and $3 \%$ glutaraldehyde in $0.1 \mathrm{M}$ PBS. SCGs were dissected free, post-fixed, stained en bloc using $2 \%$ aqueous uranyl acetate, dehydrated in ethanol, and embedded in Epon 812 (Electron Microscopy Sciences). Semithin $(0.5 \mu \mathrm{m})$ sections were stained with toluidine blue. Thin sections were poststained with uranyl acetate and lead citrate before they were viewed with the electron microscope.

In situ hybridization. In situ hybridization analysis was performed using ${ }^{33} \mathrm{P}$-labeled cRNA probes specific for $\operatorname{trk} \mathrm{A}, \operatorname{trk} \mathrm{B}$, and $t r k \mathrm{C}$ cDNA sequences. Paraffin-embedded tissue sections were mounted on Superfrost Plus slides (Fisher Scientific, Houston, TX), deparaffinized, treated with proteinase $\mathrm{K}\left(1 \mu \mathrm{g} / \mathrm{ml}\right.$ at $37^{\circ} \mathrm{C}$ for $\left.30 \mathrm{~min}\right)$, and acetylated with $0.25 \%$ acetic anhydride in $0.1 \mathrm{M}$ triethanolamine with $0.9 \% \mathrm{NaCl}$ before hybridization. Sections were hybridized with $2 \times 10^{6} \mathrm{cpm}$ of either antisense or sense probe (see below) for $16 \mathrm{hr}$ at $52^{\circ} \mathrm{C}$. Hybridized slides were rinsed twice in $4 \times$ SSC for $15 \mathrm{~min}$ at room temperature and digested with RNase A $(20 \mu \mathrm{g} / \mathrm{ml})$ for $30 \mathrm{~min}$ at $37^{\circ} \mathrm{C}$. Slides were rinsed in TE buffer alone for $30 \mathrm{~min}$ at $37^{\circ} \mathrm{C}$, washed in $2 \times \mathrm{SSC}$ at $42^{\circ} \mathrm{C}$ for $15 \mathrm{~min}$ and in $0.1 \times \mathrm{SSC}$ at $65^{\circ} \mathrm{C}$ for $15 \mathrm{~min}$, dehydrated, air-dried, and exposed to Kodak XAR-5 film for 1-3 d before dipping in undiluted NTB-2 liquid emulsion (Eastman Kodak, Rochester, NY). Slides were exposed at $4^{\circ} \mathrm{C}$, developed in D19 developer (Kodak), fixed in Kodak Fixer, dehydrated to xylenes, and coverslipped. Probes were generated from the following plasmids: (1) pMS44, a plasmid containing a 275 bp fragment encoding a portion of the extracellular domain of a rat trkA cDNA clone; (2) pFRK16, a plasmid containing a $500 \mathrm{bp}$ fragment encoding a portion of the extracellular domain of a mouse trkB cDNA clone; (3) pFL25, a plasmid containing a $600 \mathrm{bp}$ fragment encoding a portion of the extracellular domain of a mouse trkC cDNA clone; and (4) pFL26, a plasmid containing a $987 \mathrm{bp}$ fragment encoding a portion of the tyrosine kinase domain of a mouse trkC cDNA clone.

Immunocytochemistry. Immunocytochemistry for tyrosine hydroxylase (TH) was performed on fixed, frozen tissue sections (14 $\mu \mathrm{m}$ thick). Sections were treated with $0.3 \% \mathrm{H}_{2} \mathrm{O}_{2}$ followed by blocking with $0.5 \%$ BSA in PBS for 30 min at room temperature, and were incubated with a polyclonal antiserum to TH (1:1000 dilution; Eugenetech) in $0.2 \%$ Triton $\mathrm{X}-100$ in PBS overnight at room temperature. Slides were then incubated for $1 \mathrm{hr}$ at room temperature with a biotinylated secondary antibody followed by incubation with an avidin-biotin complex (Vector Laboratories, Burlingame, CA). Sections were washed for $10 \mathrm{~min}$ twice with $0.5 \%$ BSA in PBS between each step, rinsed twice in Tris-buffered saline (TBS), and reacted in a solution of $2^{\prime}, 2^{\prime}, 4^{\prime}$-diaminobenzidine $(0.25 \mathrm{mg} /$ $\mathrm{ml}$ ) in TBS containing $0.015 \% \mathrm{H}_{2} \mathrm{O}_{2}$ and $0.04 \% \mathrm{NiCl}$. Stained sections were mounted, dehydrated to xylenes, and coverslipped.

\section{RESULTS}

\section{Expression of trk genes in the developing SCG}

To determine the temporal pattern of trk gene expression in the developing mouse SCG, we carried out in situ hybridization experiments using probes specific for each of the three known members of the trk gene family. Low levels of trkA hybridization could be detected first in the SCG at E13.5, a time when this ganglion has just been formed. Robust trkA expression was observed at E15.5 and maintained throughout postnatal development (Fig. 1). TrkC transcripts were already present in the sympathetic chain at E11.5 and could be detected throughout the coalesced SCG at E13.5. Significant levels of trkC expression remained in the SCG of E15.5 embryos (Fig. 1). However, at birth trkC expression had decreased significantly and was restricted to a small number of cells (Fig. 1). Comparison of the relative numbers of cells displaying trkC hybridization in E15.5 versus $\mathrm{P} 0$ mice suggests that trkC expression is downregulated in most neurons during late embryogenesis. Because the trk $\mathrm{C}$ gene encodes several receptor isoforms, only some containing a tyrosine kinase domain (Lamballe et al., 1993; Tsoulfas et al., 1993; Valenzuela et al., 1993), we carried out additional in situ hybridization studies using a probe specific for the trkC tyrosine protein kinase sequences. This probe yielded similar results (data not shown), indicating that most of the trkC transcripts detected during SCG development correspond to those encoding the signaling TrkC tyrosine kinase receptors. Finally, trkB transcripts were not detected in sympathetic neurons at any developmental time point despite abundant expression in neighboring neuronal structures such as the nodose ganglion (data not shown).

\section{SCG development in wild-type and trkA ${ }^{-1-}$ embryos}

Ablation of the trkA gene results in the almost complete absence of sympathetic neurons in the SCG of postnatal $\mathrm{trkA}^{-/-}$mice (Smeyne et al., 1994). To determine the developmental stage at which trkA signaling is required, we analyzed the SCGs of wildtype and $t r k \mathrm{~A}^{-1-}$ mice during embryonic and postnatal development. As indicated above, the SCG does not coalesce into a discrete ganglion until $\sim$ E13.5. At this time, SCG neuroblasts and differentiating neurons are small and spherical and contain multiple nucleoli (data not shown). The number of cells in the SCG increases from E13.5 to E17.5 because of robust cellular proliferation as determined by the high number of mitotic figures (Fig. 2). From E17.5 onward, the number of SCG neurons increases slowly and stabilizes around birth because of a decrease in the number of mitotic figures as well as an increasing number of pyknotic nuclei, indicative of natural cell death (Fig. 2).

Morphological examination of the sympathetic chain in $t r k \mathrm{~A}^{-/-}$ E11.5 embryos did not reveal any obvious differences from those of their wild-type littermates. Similarly, at E13.5 the number of neurons and neuroblasts in the trk $\mathrm{A}^{-/-}$ganglia was indistinguishable from that in control mice (Fig. $2 A$ ). Two days later, the SCG of $t r k \mathrm{~A}^{-1-}$ mice contained $15 \%$ fewer cells than age-matched E15.5 wild-type embryos (Fig. $2 A$ ). Quantitative analysis of mi- 


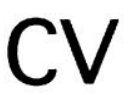

E11.5

E13.5
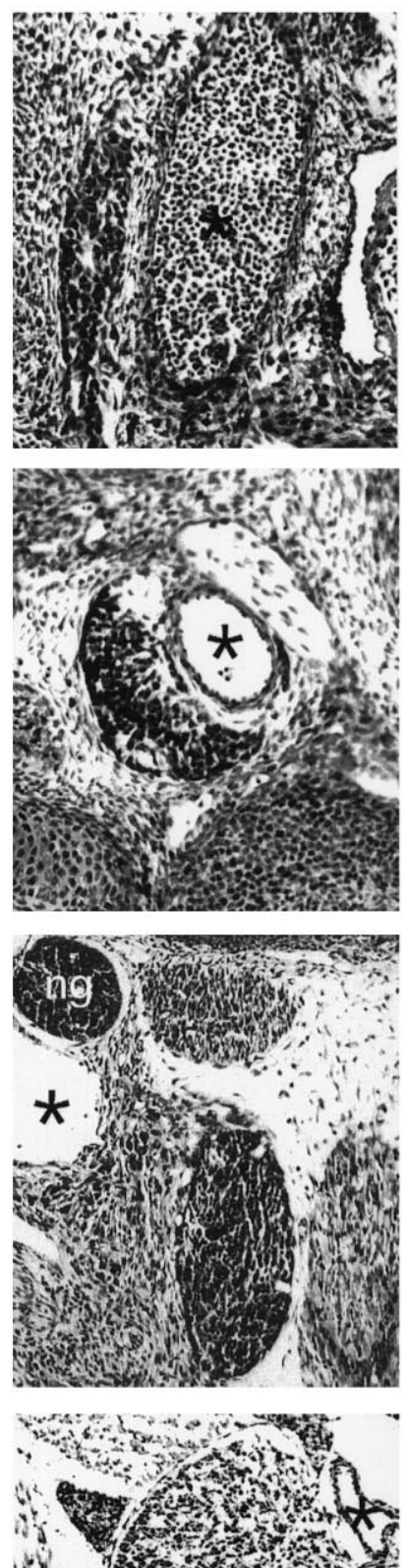

PO
trkA
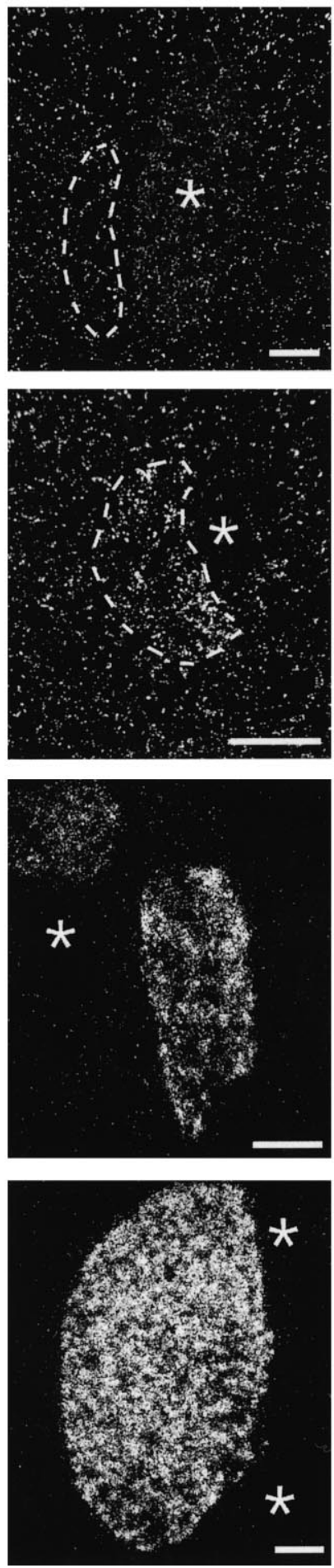

trkC
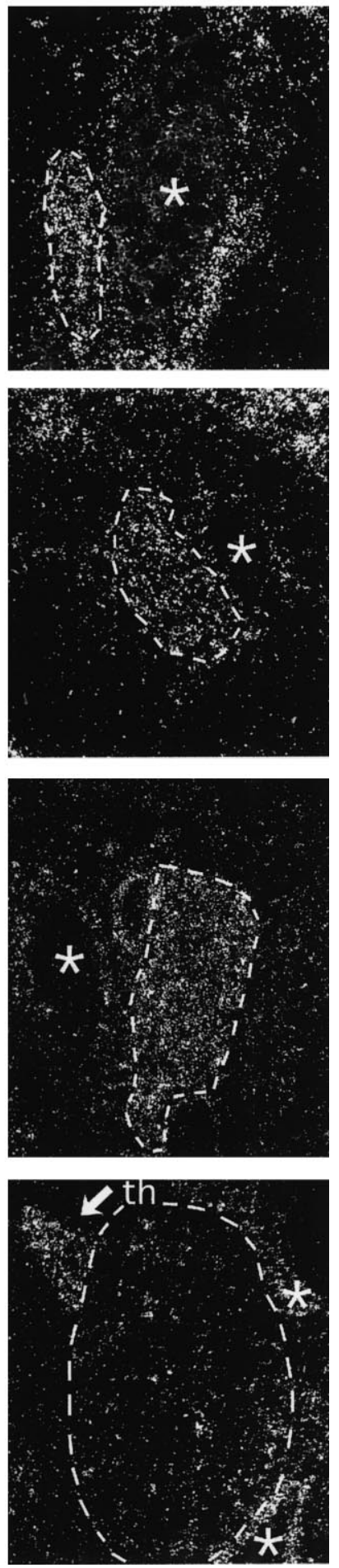

Figure 1. Developmental expression of the trkA and trkC genes in the SCGs of wild-type mice as revealed by in situ hybridization. Adjacent $5 \mu \mathrm{m}$ paraffin tissue sections were hybridized with ${ }^{33} \mathrm{P}$-labeled riboprobes specific for $t r k \mathrm{~A}$ or $t r k \mathrm{C}$. $C V$, Adjacent sections stained with cresyl violet. Asterisks identify a landmark blood vessel in each section for reference purposes. The outline of the SCG in the dark-field sections is indicated by a dotted line. ng, Nodose ganglion; th, thyroid gland. Scale bars, $10 \mu \mathrm{m}$.

totic figures and pyknotic nuclei indicates that the reduction in neuron number is attributable to an increase in the number of dying cells in the trk $\mathrm{A}^{-1-} \mathrm{SCG}$ rather than to a decrease in the rate of cell proliferation (Fig. $2 B, C$ ).
By E17.5, we observed a dramatic difference between the SCGs of wild-type and their trkA ${ }^{-1-}$ littermates, with $\sim 35 \%$ fewer cells in the mutant animals (Fig. $2 A$ ). Again, the reduction in the number of neurons appears to be attributable to an exacerbation 


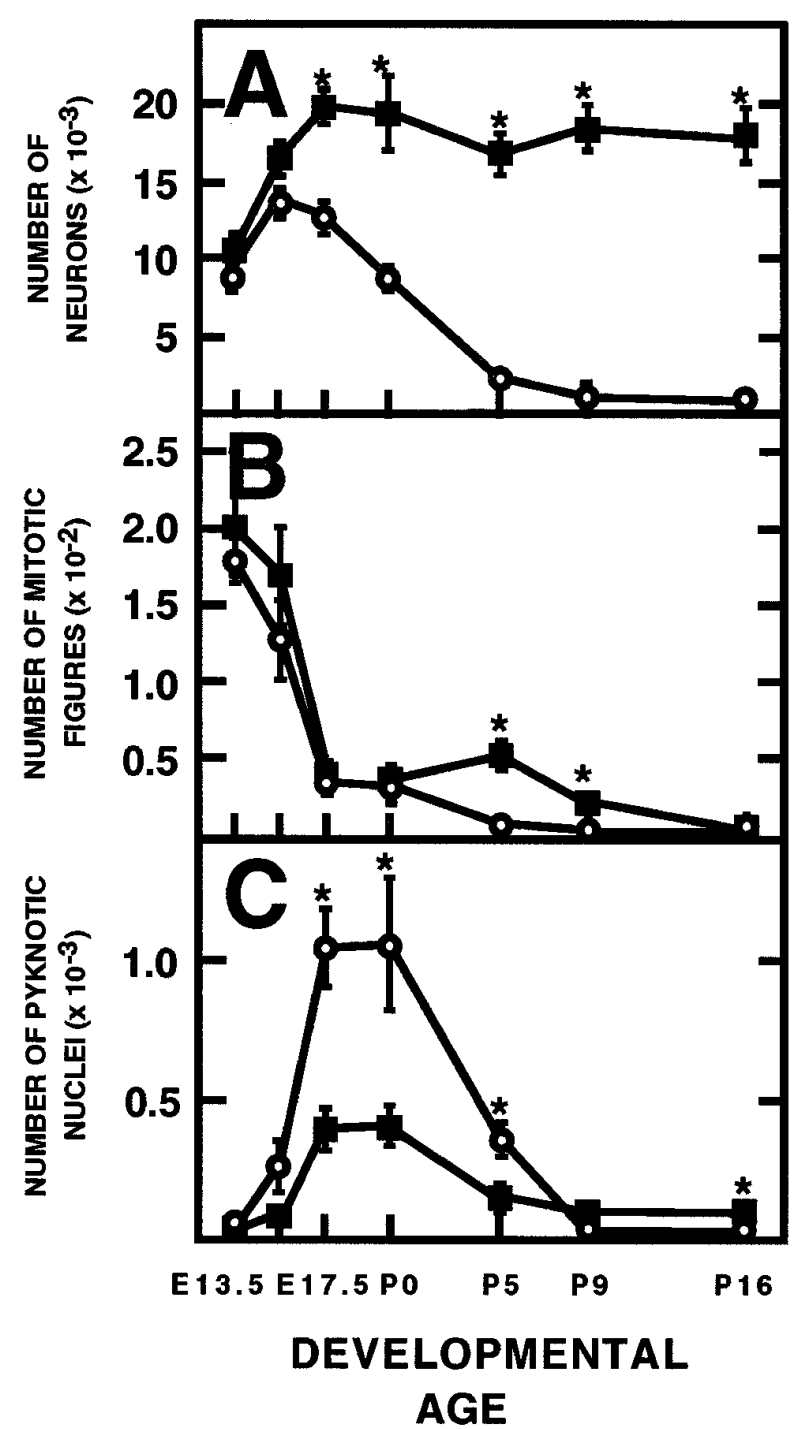

Figure 2. Quantification of $(A)$ neuron number, $(B)$ mitotic figures, and (C) pyknotic nuclei in the SCG of wild-type (filled squares) and trk $\mathrm{A}^{-1-}$ littermates (open circles). Values were obtained from at least six SCGs in each group for each time point. Asterisks indicate statistically significant differences (Student's $t$ test, $p<0.05$ ) between wild-type and $t r k \mathrm{~A}^{-1-}$ animals at a given time point. Error bars correspond to SEM.

of cell death rather than to a decrease in cell division (Fig. 2B,C). By this stage, the presence of mitotic figures has decreased considerably in both normal and mutant mice. Neurons and neuroblasts within the SCG of $t r k \mathrm{~A}^{-/-}$mice and their wild-type littermates display similarly abundant immunoreactivity for the catecholamine synthetic enzyme $\mathrm{TH}$, indicating that these cells exhibit this phenotypic marker in the absence of functional TrkA receptors.

\section{SCG development in wild-type and trkA ${ }^{-1-}$ postnatal mice}

By birth, trkA $\mathrm{A}^{-/-}$mice exhibit $\sim 50 \%$ fewer SCG neurons than their wild-type littermates (Fig. $2 A$ ). This pattern of exacerbated cell death continues postnatally, reaching a near complete loss of SCG neurons by P9 (Fig. $2 A$ ). During the early postnatal period (P5), wild-type mice undergo a transient increase in the number of mitotic figures, which likely represents proliferation of glial cells (Hendry, 1977; Hall and Landis, 1992) (Fig. 2). Interestingly, we did not observe this increase in mitosis in the $t r k \mathrm{~A}^{-1-}$ animals. To determine the nature of these dividing cells, P5 mice were injected twice with bromodeoxyuridine (BRdU) and killed $2 \mathrm{hr}$ later. Whereas the wild-type ganglia displayed many BRdU labeled nuclei, ganglia from the trkA $^{-1-}$ mice exhibited only a few labeled cells (data not shown). Double labeling with $\mathrm{TH}$ antibodies revealed that BRdU was not located in principal neurons but, rather, in TH-negative non-neuronal cells (data not shown). These results indicate that postnatal gliogenesis in the SCG is significantly reduced in $t_{r k \mathrm{~A}^{-/-}}$mice.

\section{Morphological characterization of wild-type and trkA $^{-1-}$ SCG neurons in postnatal mice}

To characterize the defects observed in postnatal trkA $\mathrm{A}^{-1-}$ animals, we analyzed the SCGs of neonatal and P5 trkA ${ }^{-1-}$ and wild-type littermate animals in semithin sections (Fig. 3). At P1, a majority of neurons in neonatal wild-type mice were medium in size and ovoid in shape. They had large, eccentric nuclei with prominent nucleoli and displayed abundant, moderately stained cytoplasm (Fig. 3A). Less mature neurons, characterized by smaller nuclei and less cytoplasmic volume, were observed, as well as profiles of degenerating neurons with darkly stained, condensed cytoplasm and nuclei, or having a foamy appearance (Fig. $3 A$ ). Relatively few glial cell profiles were evident at this time.

In contrast, the SCG of $\mathrm{P} 1 \operatorname{trk}^{-/-}$mice had few, if any, cells with the appearance characteristic of maturing, postmitotic sympathetic neurons. Instead, many of these cells resembled embryonic neurons (Fig. 3B), small and irregularly shaped with a relatively large rounded nucleus and only a thin rim of cytoplasm. These cells could be distinguished from glial cells, which had small, darkly stained and irregularly shaped nuclei (Fig. 3B). The mutant SCG also displayed many profiles of degenerating cells with a dark, condensed nucleus and darkly stained debris (Fig. 3B).

The morphological differences between the SCG of wild-type and $t r k \mathrm{~A}^{-1-}$ mice were even more striking at P5. wild-type neurons had doubled or tripled in size and had one or more satellite glial cells associated with their cell body (Fig. $3 C$ ). Very few neuronal profiles could be identified in semithin sections of the P5 mutant ganglia, and those that were present were very immature in appearance (Fig. 3D). Many cells in the $\mathrm{trkA}^{-/-}$SCG had the appearance of glial cells with darkly stained elongate nuclei and were associated with lightly stained regions, presumably containing processes (Fig. 3D). Degenerating profiles were still common in the mutant ganglia at this time, often appearing as darkly stained debris (Fig. 3D).

Ultrastructural analysis confirmed the morphological differences between the cells of the wild-type and $t r k \mathrm{~A}^{-1-}$ SCG at P5 (Fig. 4A,B). No mature-looking sympathetic neurons could be found in the P5 trkA ${ }^{-1-}$ SCG (Fig. 4B), but we did observe glial cells, fibroblasts, and small intensely fluorescent (SIF) cells (see below) (Fig. 4B,C). Bundles of unmyelinated axons were also observed in the SCG at this time (Fig. $4 D, E$ ). However, axons in the mutant SCG were smaller in diameter and less well ensheathed than those observed in the littermate controls (Fig. 4D,E).

In addition to the principal sympathetic neurons, sympathetic ganglia contain a subpopulation of cells of sympathoadrenal lineage known as SIF cells. SIF cells, which are thought to be interneurons or neuroendocrine cells (Elfvin et al., 1993), are smaller than principal neurons $(10-15 \mu \mathrm{m}$ in diameter compared with $20-40 \mu \mathrm{m}$ ) and contain many large dense-cored vesicles 


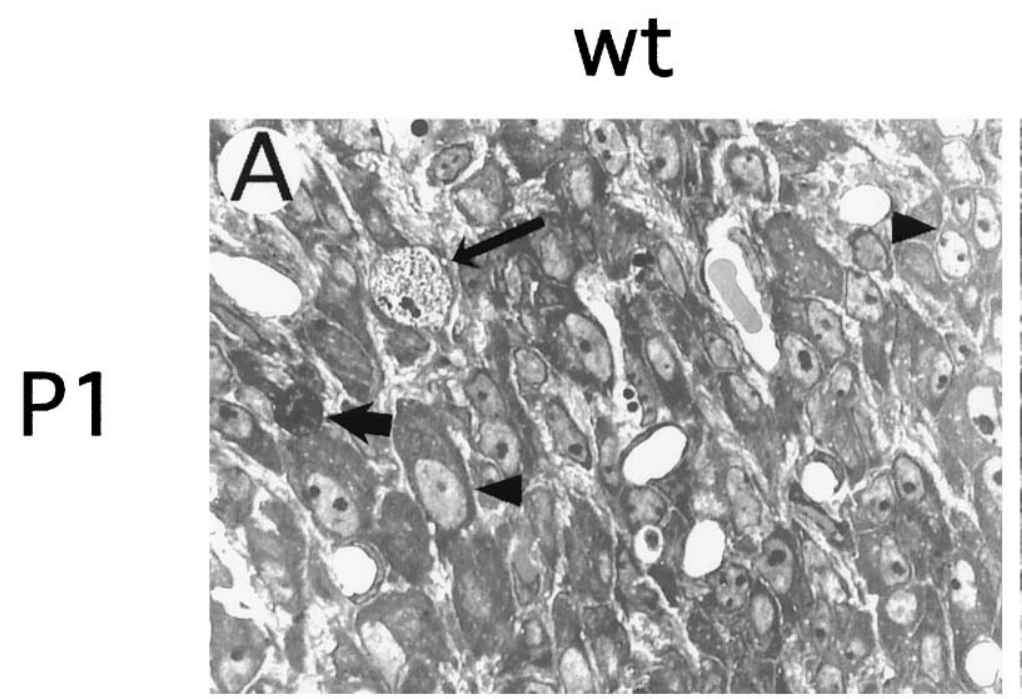

\section{$\operatorname{trkA}(-/-)$}
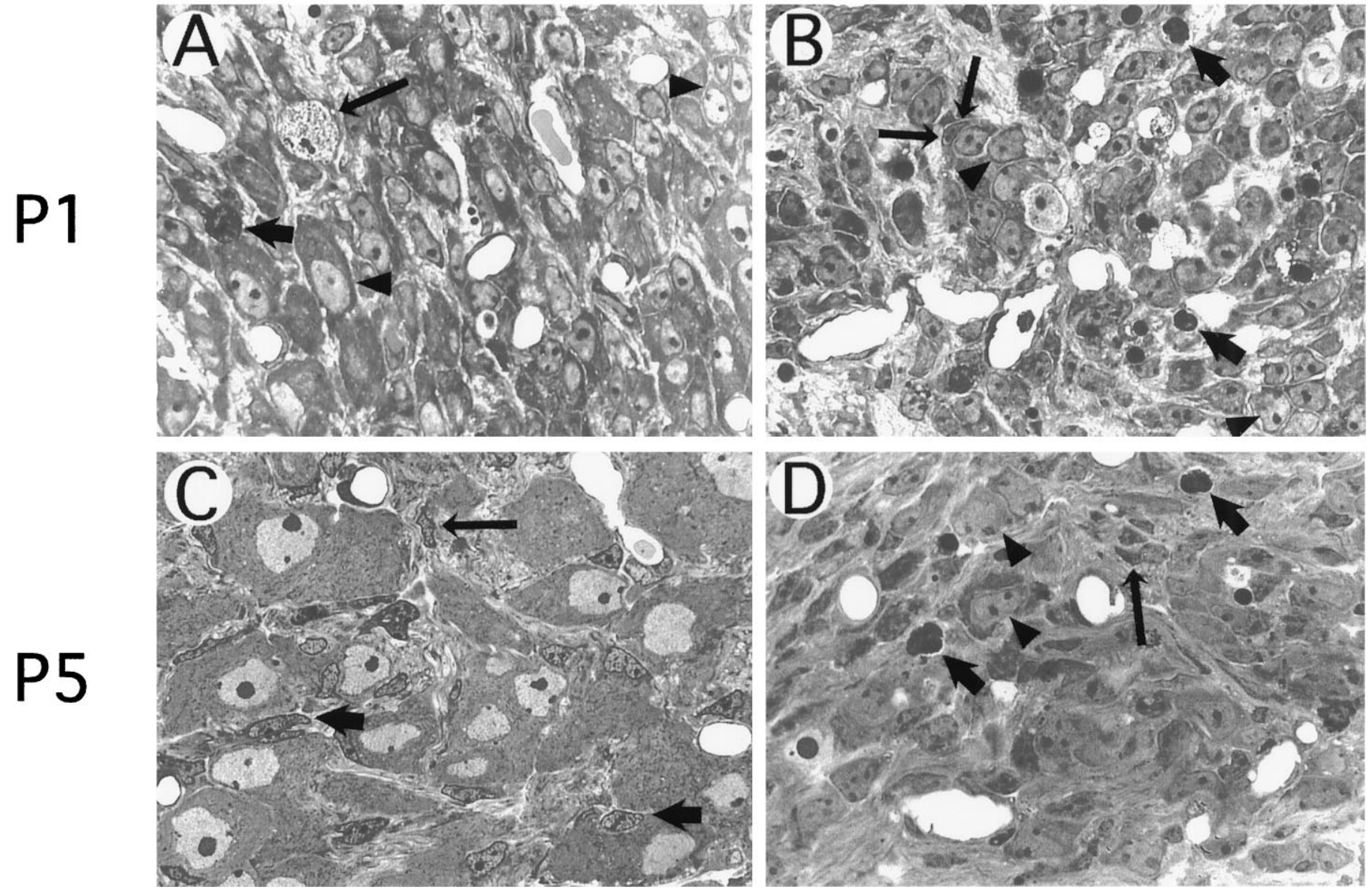

Figure 3. One micrometer semithin plastic sections of SCGs of wild-type and trk $\mathrm{A}^{-1-}$ mice. $A$, P1 wild-type SCG. A majority of neurons are medium in size and ovoid in shape (left arrowhead). A small proportion of neurons are smaller and have less cytoplasm (right arrowhead). The arrow indicates a degenerating neuron. The thin arrow identifies a foamy cell. $B, \mathrm{P} 1$ trk $\mathrm{A}^{-/-} \mathrm{SCG}$. A majority of neurons are small in diameter and irregular in shape (arrowheads). Nuclei appear more darkly stained than those of wild-type neurons, and little cytoplasm is evident. Neurons also appear more closely clustered than those in sections of wild-type ganglia. Many pyknotic cells are present (arrows). C, P5 wild-type SCG. Neurons are significantly larger than at P1, with increases in both nuclear and cytoplasmic volume. Both satellite (arrows) and Schwann cells (thin arrow) are prominent in association with cell bodies and axons, respectively. $D, \mathrm{P} 5 \mathrm{trk \textrm {A } ^ { - 1 - }}$ SCG. Very few neurons remain. Those present display an immature morphology similar to that observed in sections of P1 ganglia (arrowheads). Cells with smaller and more darkly stained nuclei resemble glial cells. Some pyknotic profiles remain (arrows), but they are reduced in number in comparison to P1. Magnification, $475 \times$.

(Fig. 4C). Interestingly, trk $\mathrm{A}^{-1-}$ animals contain the normal complement of these cells, which appear morphologically indistinguishable from those of wild-type ganglia (Fig. $4 C$ ). Therefore, expression of TrkA receptors appears to be required for the survival of principal neurons, but not of SIF cells.

\section{Sympathetic target innervation in normal and trkA null mice}

The above results indicate that cell death within the SCG of trk $\mathrm{A}^{-/-}$mice takes place after E13.5, the time of scheduled onset of trkA expression. However, certain developmental programs, such TH expression, appear to be independent of the presence of TrkA receptors. Indeed, the SCGs of $t r k \mathrm{~A}^{-1-}$ mice exhibit normal levels of TH immunoreactivity at both E13.5 and E15.5 (Fig. 5). To determine whether TrkA receptors are required for other events of sympathetic development, we examined whether the neurons of $t r k \mathrm{~A}^{-/-}$SCGs extend axons that are capable of reaching their targets. To this end, we assessed neurite outgrowth in wild-type and trk $\mathrm{A}^{-/-}$SCGs using TH immunocytochemistry because TH is localized in sympathetic axons as well as cell bodies.

A substantial number of TH-positive neurites could be observed extending from the SCG in wild-type E13.5 embryos (Fig. $5 A$ ). These fibers traveled a limited, albeit significant, distance toward the neighboring vasculature, one of the first sympathetic targets to be innervated (Rubin, 1985). No differences in neurite outgrowth were observed between $\operatorname{trk} \mathrm{A}^{-/-}$mice and their wildtype littermates at this developmental stage (Fig. 5B). Similar results were obtained when we analyzed mice at E15.5, a time when trkA transcripts are highly expressed in the wild-type animals (Fig. 5C,D). Bundles of TH-immunoreactive fibers projecting from different areas of the ganglion, likely representing the nascent postganglionic nerves, were found in both wild-type and mutants SCGs (Fig. 5B,D). These observations suggest that TrkA receptors are not required for initial sympathetic axonal growth.

Next, we examined whether sympathetic axons in trk $\mathrm{A}^{-1-}$ mice 

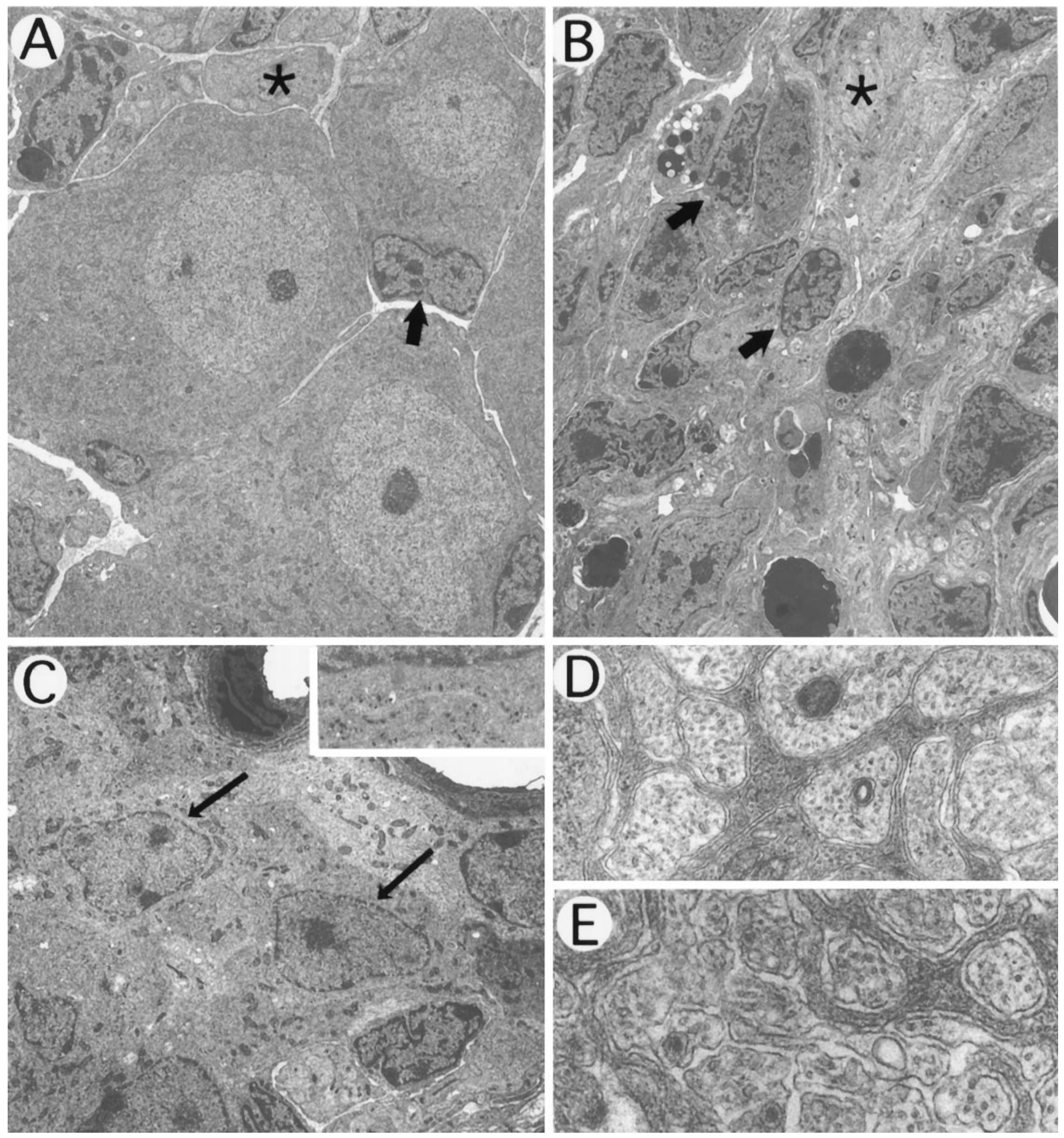

Figure 4. Ultrastructural appearance of the SCGs of wild-type and trk $\mathrm{A}^{-1-} \mathrm{P} 5$ mice. $A, \mathrm{P} 5$ wild-type SCG. Neurons are large with abundant organelles. Satellite cells are associated with neurons (arrow). Bundles of axons (asterisk) are present between the neuronal somata. $B, C, \mathrm{P} 5$ trk $\mathrm{A}^{-1-} \mathrm{SCG}$. There are few cells with neuronal properties. The SCG is mostly comprised of glial cells (arrows), fibroblasts, and SIF cells (thin arrows) whose characteristic complement of granules is shown at higher magnification in the inset. Axons in wild-type SCG $(D)$ are larger in diameter and more completely ensheathed than those in $\operatorname{trk} \mathrm{A}^{-1-}$ ganglia $(E)$. Magnification: $A-C, 250 \times ; D, E, 15,000 \times$.

were capable of innervating the submaxillary gland, a more distal target. Coarse TH-immunoreactive fibers were first observed in the wild-type submaxillary gland at E15.5 (Fig. 6A). From this time on, the number of TH-positive fibers continues to increase until the entire gland becomes densely innervated by P0 (Fig. 6B).
When sections from trkA ${ }^{-1-}$ mutant mice were examined, no significant levels of innervation could be detected in the submaxillary gland throughout this period (Fig. $6 B, D$ ), despite the presence of significant $\mathrm{TH}$ immunoreactivity in the surviving SCG neuronal cell bodies of these animals. These results suggest that 


\section{wt}

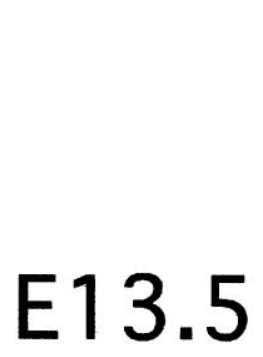

A

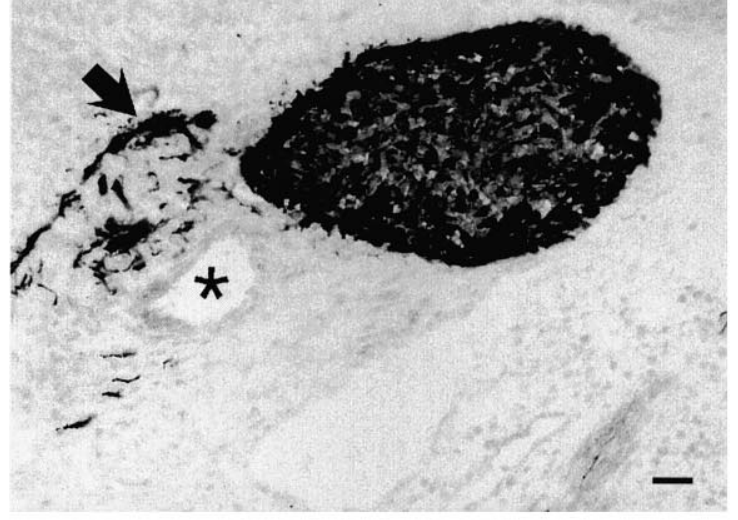

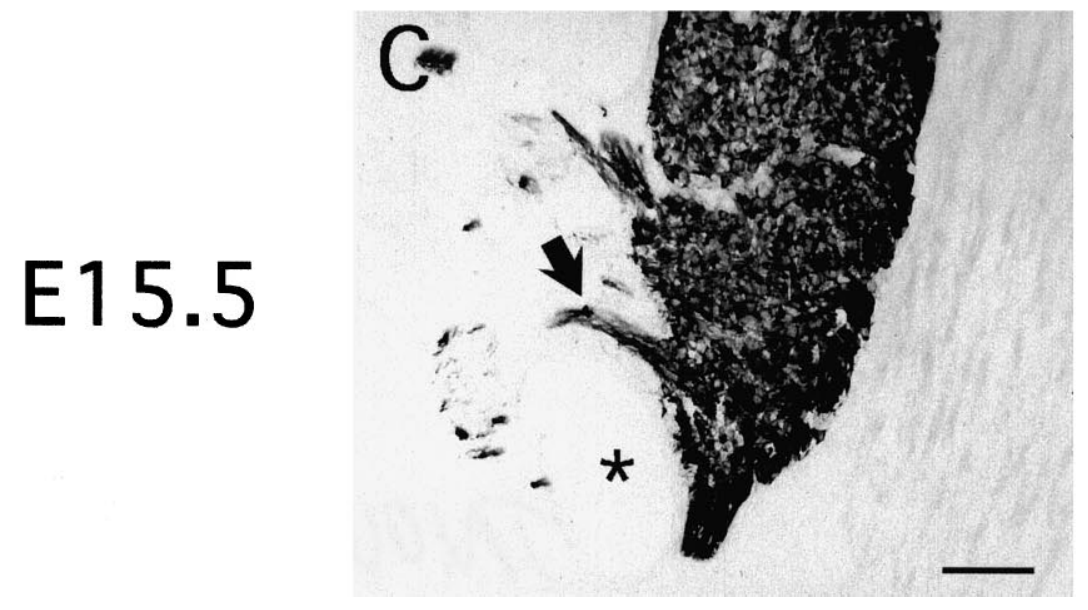

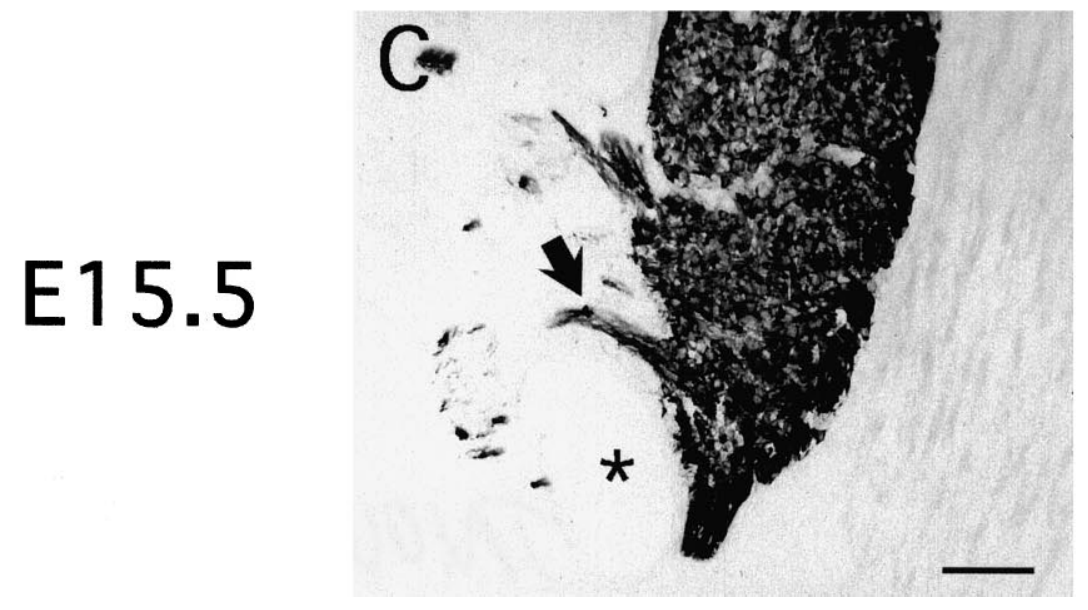

\section{$\operatorname{trkA}(-/-)$}
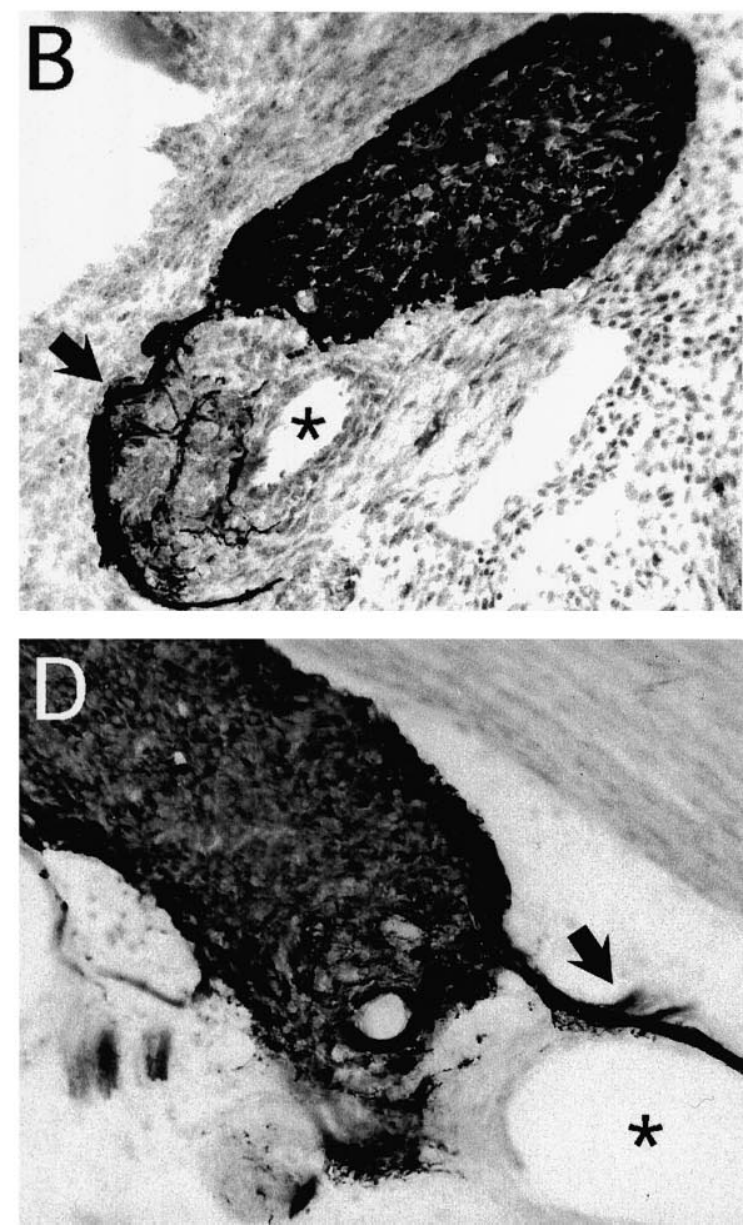

Figure 5. Immunocytochemical analysis of tyrosine hydroxylase in the SCGs of wild-type and trk $\mathrm{A}^{-1-}$ mice. A, B, Arrows indicate plexes of tyrosine hydroxylase-positive fibers extending from the SCG, often in the vicinity of the nearby vasculature (asterisk). $C, D$, Arrows indicate tyrosine hydroxylaseimmunoreactive fibers exiting the SCG in bundles, likely representing the nascent sympathetic nerves. Asterisks identify a neighboring blood vessel. Scale bars, $5 \mu \mathrm{m}$.

TrkA receptors are required to sustain axonal growth to reach distal targets.

\section{SCG development in trkB ${ }^{-1-}$ and trkC $^{-/-}$mice}

Consistent with the lack of trkB expression in embryonic and postnatal sympathetic neurons, no defects were observed in the $\mathrm{SCG}$ of $t r k \mathrm{~B}^{-1-}$ mice (data not shown). However, $\operatorname{trk} \mathrm{C}$ is abundantly expressed from E11.5 to E15.5 (see Fig. 1), thus raising the possibility that events in early sympathetic development require NT-3/TrkC signaling. Indeed, mice lacking NT-3 display a 50\% reduction in the number of SCG neurons (Ernfors et al., 1994; Fariñas et al., 1994; ElShamy et al., 1996). Surprisingly, analysis of SCG neuron number in trkC $\mathrm{C}^{-/-}$mice revealed no significant differences from their wild-type littermates during embryonic development and at postnatal time points (Fig. 7). In addition, trkC $^{-1-}$ SCG neurons exhibited normal $\mathrm{TH}$ immunoreactivity and target innervation (data not shown). These results suggest that TrkC receptors, although expressed during the early stages of sympathetic development, are not essential for the genesis or survival of sympathetic neurons in vivo.

Previous studies have demonstrated that NT-3 promotes the survival of rat sympathetic neuroblasts in culture, whereas neurons from older developmental stages require NGF (Birren et al., 1993; DiCicco-Bloom et al., 1993). These observations have led to a model in which NT-3 signaling, presumably mediated by TrkC receptors, leads to a switch in neurotrophin dependency by inducing expression of TrkA receptors (Verdi and Anderson, 1994). To determine whether NT-3 signaling through TrkC receptors triggers expression of TrkA receptors in vivo, we examined the presence of trkA transcripts in the SCG of $t r k \mathrm{C}^{-1-}$ mice at E15.5, a time of robust trkA expression in the developing SCG. As illustrated in Figure 8, $A$ and $B$, we observed normal levels of trkA gene expression in both wild-type and $t_{k} \mathrm{C}^{-1-} \mathrm{E} 15.5$ embryos. Likewise, trkC expression was not affected in trk $\mathrm{A}^{-1-}$ embryos (Fig. $8 C, D$ ), indicating that, in vivo, expression of the trkA and trk $\mathrm{C}$ genes is not regulated by each other.

\section{DISCUSSION}

The generation of mice lacking each of the known neurotrophins and their cognate receptors is making it possible to decipher the specific role that these trophic factors play in the development of 
wt
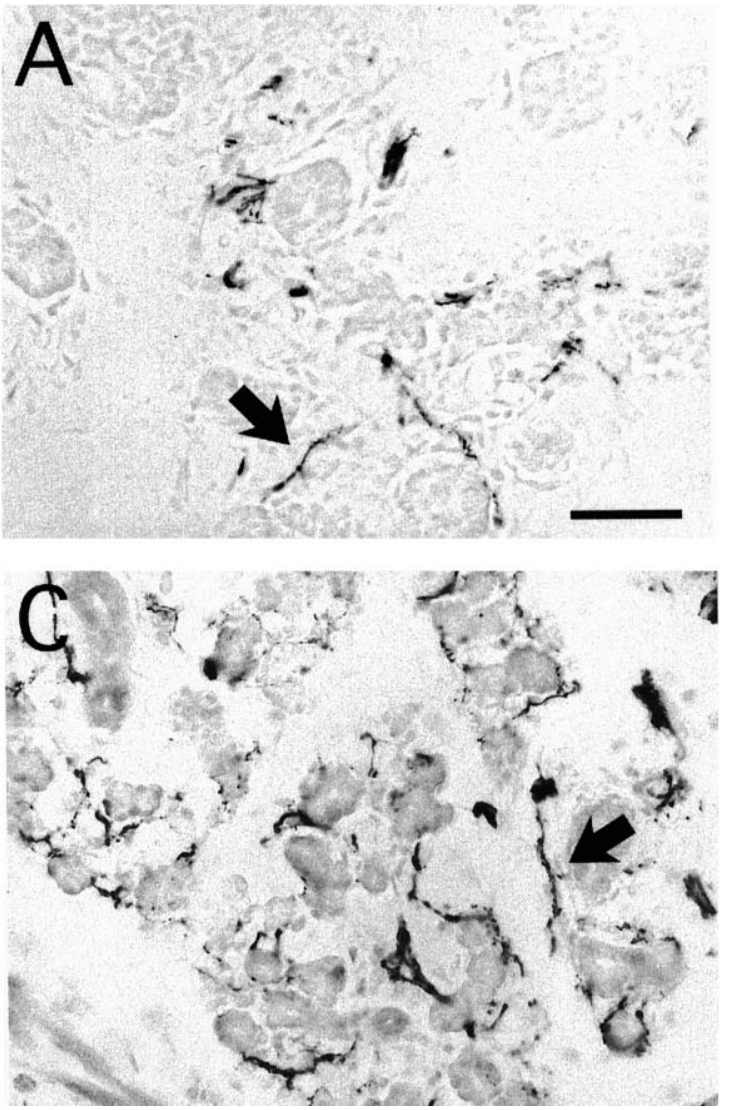

\section{$\operatorname{trkA}(-/-)$}
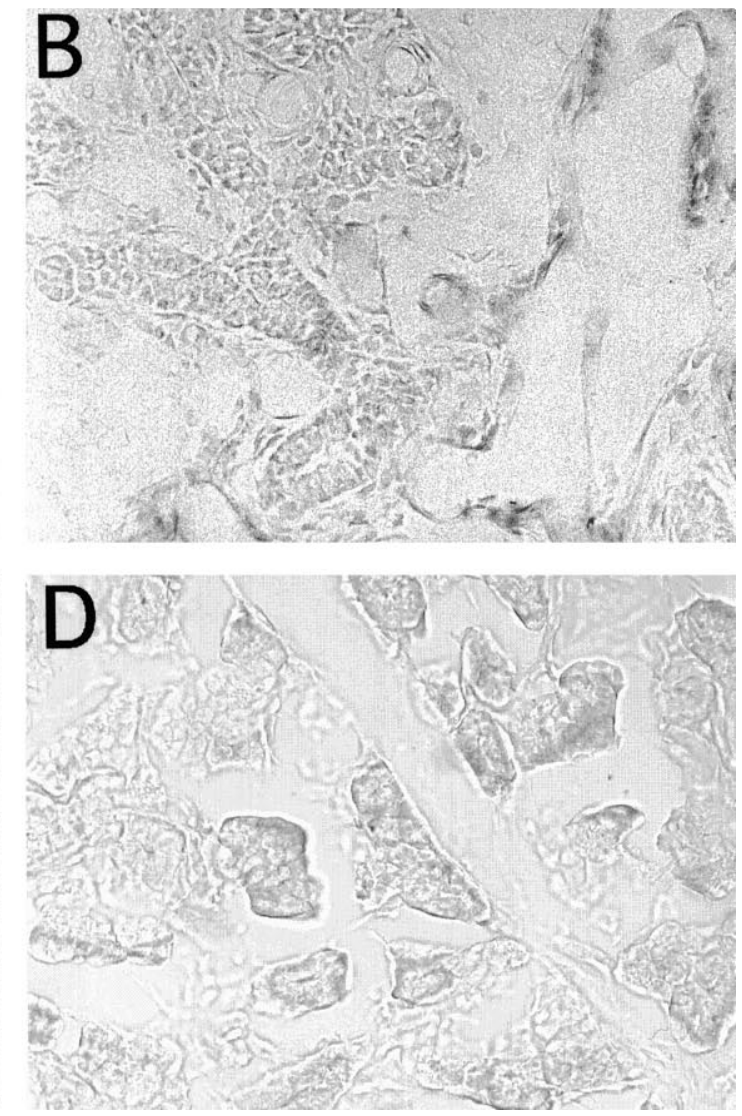

Figure 6. Tyrosine hydroxylase immunoreactivity in the submaxillary gland of wild-type and trk $\mathrm{A}^{-1-}$ mice. $A, C$, Arrows indicate innervating fibers of sympathetic origin. Scale bar, $3 \mu \mathrm{m}$.

the mammalian nervous system. In this study, we have analyzed the role of each of the three members of the Trk family of receptors in the development of sympathetic neurons. As previously observed in rats (Ernfors et al., 1992; Birren et al., 1993; DiCicco-Bloom et al., 1993), expression of Trk receptors in the mouse SCG is developmentally regulated. TrkC transcripts appear in sympathetic neurons before the coalescence of the SCG (E11.5). trkC expression declines during late gestation and remains restricted to a small subset of cells postnatally. trkA transcripts can be first detected at E13.5/E14.5, a time that coincides with the requirement of sympathetic neurons for NGF in vitro (Coughlin and Collins, 1985; Wyatt and Davies, 1995). trkA expression increases by E15.5 and remains high into adulthood.

Previous studies have shown that newborn $t r k \mathrm{~A}^{-1-}$ mice have significantly fewer sympathetic neurons than their wild-type littermates (Smeyne et al., 1994). Our detailed analysis of neuron number, mitotic figures, and pyknotic nuclei during embryogenesis and early postnatal development indicates that loss of sympathetic neurons in these mice is attributable to increased cell death and not to a defect in neuroblast proliferation. Moreover, the observation that cell death in trk $\mathrm{A}^{-/-}$mutant mice extends along a time course parallel to that of their wild-type siblings (albeit in greater magnitude) suggests an exacerbation of a normal process rather than an impairment of any other developmental event(s). These observations are consistent with the notion that NGF plays a role in promoting sympathetic neuronal survival during late, but not early, embryogenesis (Barde, 1989; Vogel, 1994).

In contrast to the devastating effects of ablating the trkA gene on the survival of sympathetic principal neurons, SIF cell development appears to be unaffected by the absence of TrkA receptors. This observation is consistent with the concept that SIF cells and principal sympathetic neurons have independent developmental histories (Hall and Landis, 1991). Glial cells, although reduced in number in the mutant ganglia, also appear morphologically normal. The reduced number of glial cells is likely to be a consequence of the absence of postnatal ( $\sim$ P5) glial proliferation, possibly attributable to the absence of neuron-derived glial growth factors (such as neuregulins) in the mutant mice (Carraway and Burden, 1995).

Sympathetic neurons of $t r k \mathrm{~A}^{-1-}$ mice are not impaired in their ability to extend neurites during early development. In fact, numerous TH-positive fibers can be found extending from the trkA ${ }^{-1-}$ SCG at E13.5 and E15.5, in patterns indistinguishable from those of age-matched controls. Elaborate plexes of fibers were observed extending toward the neighboring vasculature at E13.5. By E15.5, both wild-type and $t r k \mathrm{~A}^{-1-}$ mice display thick bundles of TH-positive fibers coursing along blood vessels, the normal trajectory taken by developing sympathetic fibers as they grow toward more distal targets (Shibamori et al., 1994). These observations indicate that TrkA signaling is not required for initial 


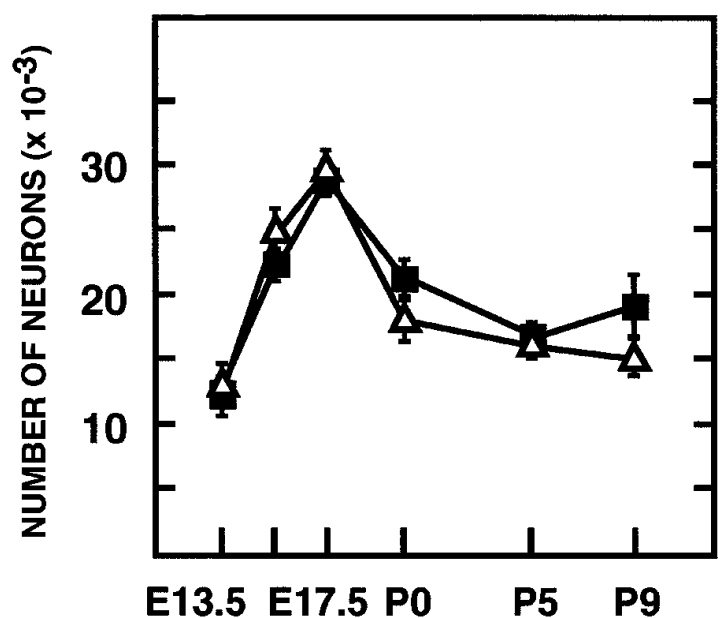

\section{DEVELOPMENTAL AGE}

Figure 7. Number of neurons in the SCG of wild-type (filled squares) and trkC $^{-1-}$ (open triangles) mice. Values were obtained from at least six SCGs in each group for each time point. No statistical differences between groups were found using Student's $t$ test $(p<0.05)$. Error bars correspond to SEM.

axonal outgrowth and possibly not for innervation of proximal vascular targets during development.

In wild-type E15.5 embryos, sympathetic fibers have begun to reach more distal targets, such as the submaxillary gland. In the trk $\mathrm{A}^{-/-}$E15.5 embryos, however, we did not observe TH-positive fibers in the submaxillary gland, despite abundant $\mathrm{TH}$ expression within SCG neuron cell bodies and their proximal processes. This defect in submaxillary gland innervation in the TrkA mutant mice is not attributable to a slower rate of axonal growth because immunocytochemical analysis of neonatal animals also showed lack of TH-positive fibers in the submaxillary gland. Therefore, sympathetic axons cannot reach this distal target in the absence of TrkA receptors. Whereas we cannot rule out the possibility of a primary defect in axon growth in $t r k \mathrm{~A}^{-/-}$animals, we favor the hypothesis that defects in distal target innervation are a direct consequence of the massive neuronal cell death in the developing SCG. If so, sympathetic neurons lacking TrkA receptors, and therefore devoid of trophic support, must die (or at least initiate cell death) before their processes reach their distal targets.

Regardless of the mechanism(s) responsible for the lack of distal target innervation in the $\operatorname{trk} \mathrm{A}^{-1-}$ mice, our results indicate that sympathetic neurons require trophic support before reaching these distal targets. These observations are at variance with certain aspects of the neurotrophic hypothesis, which proposes that neurons become neurotrophin-dependent after target innervation, thus allowing target-derived trophic factors to control the number of neurons that will survive in the adult animal. Whereas our results do not challenge this fundamental tenet, they suggest that NGF may control sympathetic neuron number as part of a developmental program independent of complete target innervation. Similar results have been obtained recently when we analyzed sensory neurons of the dorsal root ganglia (DRG). In this case, the peak of neuronal cell death was observed at E13.5, a time

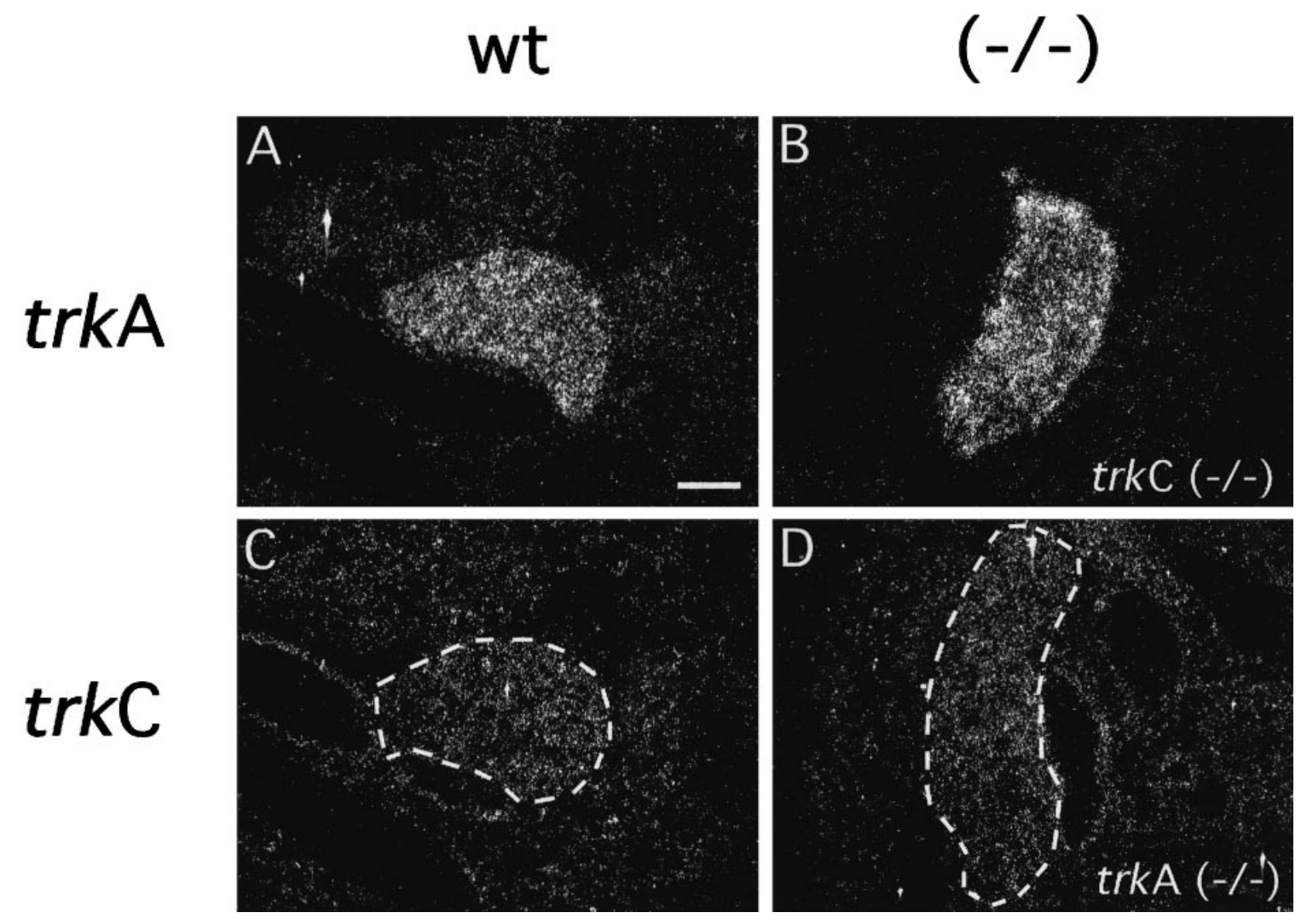

Figure 8. $\quad$ trkA and trkC gene expression in the $\mathrm{SCG}$ of $\mathrm{E} 15.5 \mathrm{trkC} \mathrm{C}^{-/-}$and $t r k \mathrm{~A}^{-/-}$embryos, respectively. Sections derived from $(A)$ wild-type and $(B)$ trkC $\mathrm{C}^{-/-}$ animals were submitted to in situ hybridization using a probe specific for trkA transcripts. Sections derived from $(C)$ wild-type and $(D)$ trk $\mathrm{A}^{-1-}$ animals hybridized with a probe specific for $t r k \mathrm{C}$ transcripts. The SCG shown in $D$ appears larger than that in $C$ because they are in different planes of section. Scale bar, $10 \mu \mathrm{m}$. 
when projections from the trkA-expressing DRG sensory neurons have not reached their distal cutaneous targets (White et al., 1996). Whether innervation of proximal targets, such as the nearby vasculature in the case of sympathetic neurons, plays a role in providing trophic support before neighboring neurons reach their distal targets is a possibility that remains to be explored.

A number of in vitro studies have indicated that rat sympathetic neuroblasts undergo a developmental switch in their neurotrophin dependence, from NT-3 to NGF (Birren et al., 1993; DiCiccoBloom et al., 1993; Verdi and Anderson, 1994). The sequential expression of trkC and trkA transcripts within the developing mouse SCG is consistent with this hypothesis. However, our in vivo studies do not support the hypothesis that NT-3 signaling induces expression of TrkA receptors (Verdi and Anderson, 1994). Instead, our studies using mice defective in either TrkA or TrkC receptors indicate that regulation of the genes encoding these receptors is independent of the presence of each other.

Another unexpected observation reported in this study is the lack of neuronal deficits in the SCG of $t r k \mathrm{C}^{-1-}$ mice. The presence of abundant trkC transcripts during the early developmental stages of sympathetic development suggests a critical role for TrkC receptors. Moreover, mice defective in its cognate ligand, NT-3, display a 50\% reduction in SCG neurons (Ernfors et al., 1994; Fariñas et al., 1994; ElShamy et al., 1996). Indeed, the observed differences between NT-3 and trkC mutant mice may not be limited to the sympathetic system since overall, the phenotype of NT-3 $3^{-/-}$mice is substantially more severe than that of $t r k \mathrm{C}^{-/-}$ animals (Ernfors et al., 1994; Fariñas et al., 1994; Klein et al., 1994). It could be argued that these differences might be attributable to the possible presence of noncatalytic TrkC receptor isoforms in the $t r k \mathrm{C}^{-1-}$ mice (Klein et al., 1994). However, this hypothesis is unlikely since these receptors do not mediate NT-3 signaling, at least in vitro (Tsoulfas et al., 1993; Valenzuela et al., 1993).

It is possible that some of the defects observed in the NT- $3^{-1-}$, but not in the $t r k \mathrm{C}^{-1-}$, mice might be attributed to NT-3 signaling through TrkA and/or TrkB receptors. It has been reported recently that, in vitro, NT-3 supports the survival of sensory and sympathetic neurons derived from mice lacking signaling TrkC receptors (Davies et al., 1995). Moreover, sympathetic neurons from mice lacking NGF reach the submaxillary gland, although they do not form secondary processes (H. Phillips and S. Landis, unpublished observations), thus suggesting that a neurotrophin other than NGF can support, at least partially, sympathetic axonal growth through TrkA receptors. Recently, ElShamy et al. (1996) have reported that the reduced number of postmitotic neurons in the homozygous NT-3 mutant mice is caused by apoptosis of sympathetic neuroblasts at E11.5. These observations raise the possibility that NT-3 may act through TrkA receptors at a developmental stage before the onset of NGF expression (E14.5E15.5). However, no such apoptotic events were observed in sympathetic neuroblasts of $\operatorname{trkA}^{-/-}$mice, indicating that NT-3 cannot signal exclusively through TrkA receptors at this time in development.

A more likely scenario is that NT-3 can signal through either TrkA or TrkC receptors during the short developmental window in which these receptors are coexpressed throughout the developing SCG. If so, loss of the neurotrophic factor NT-3, but not of only one of the two receptors TrkA or TrkC, would result in neuronal deficits. This hypothesis can be tested by comparing the number of apoptotic neuroblasts in NT-3 $3^{-1-}$ mice versus those in mice lacking TrkA and TrkC receptors. However, only 1 of 16 embryos derived from crosses between double heterozygous trk $\mathrm{A}^{+/-} ;$trk $\mathrm{C}^{+/-}$mice would yield the desired phenotype. Moreover, the presence of apoptotic neuroblasts in these doubleknockout embryos will be obscured by the onset of neuronal cell death caused by the absence of TrkA receptors.

Analysis of genetically engineered mice lacking neurotrophins and their signaling Trk receptors is making it possible to analyze neuronal development, at least in the peripheral nervous system, with a degree of detail and sophistication that was not possible before. These studies are likely to expand and refine hypotheses drawn in vitro and in vivo studies using conventional mice. The demonstration that TrkC receptors are not essential for SCG development despite their expression in early embryos and the observation that sympathetic neurons of $\mathrm{rkA}^{-1-}$ mice do not innervate distal targets are just two examples of the value of these mutant mice to study the development of the mammalian nervous system.

\section{REFERENCES}

Barbacid M (1994) The Trk family of neurotrophin receptors. J Neurobiol 25:1386-1403.

Barde YA (1989) Trophic factors and neuronal survival. Neuron 2:1525-1534.

Birren S, Liching L, Anderson DJ (1993) Sympathetic neuroblasts undergo a developmental switch in trophic dependence. Development 119:597-610.

Chao MV (1994) The p75 neurotrophin receptor. J Neurobiol 25: $1373-1385$.

Carraway KL, Burden SJ (1995) Neuregulins and their receptors. Curr Opin Neurobiol 5:606-612.

Chun LL, Patterson PH (1977) Role of nerve growth factor in the development of rat sympathetic neurons in vitro. II. Developmental studies. J Cell Biol 75:705-711.

Coughlin MD, Boyer DM, Black IB (1977) Embryonic development of a mouse sympathetic ganglion in vivo and in vitro. Proc Natl Acad Sci USA 74:3438-3442.

Crowley C, Spencer SD, Nishimura MC, Chen KS, Pitts-Meek S, Armanini MP, Ling LH, McMahon SB, Shelton DL, Levinson AD, Phillips HS (1994) Mice lacking nerve growth factor display perinatal loss of sensory and sympathetic neurons yet develop basal forebrain cholinergic neurons. Cell 76:1-20.

Davies AM, Minichiello L, Klein R (1995) Developmental changes in NT-3 signalling via TrkA and TrkB in embryonic neurons. EMBO J 14:4482-4489.

DiCicco-Bloom E, Friedman WJ, Black IB (1993) NT-3 stimulates sympathetic neuroblast proliferation by promoting precursor survival. Neuron 11:1101-1111.

Elfvin LG, Lindh B, Hokfelt T (1993) The chemical neuroanatomy of sympathetic ganglia. Annu Rev Neurosci 16:471-507.

Elkabes S, Dreyfus CF, Schaar DG, Black IB (1994) Embryonic sensory development: local expression of neurotrophin-3 and target expression of nerve growth factor. J Comp Neurol 341:204-213.

ElShamy WM, Linnarsson S, Lee K-F, Jaenisch R, Ernfors P (1996) Prenatal and postnatal requirements of NT-3 for sympathetic neuroblast survival and innervation of specific targets. Development 122:491-500.

Ernfors P, Merlio JP, Persson H (1992) Cells expressing mRNA for neurotrophins and their receptors during embryonic rat development. Eur J Neurosci 4:1140-1158.

Ernfors P, Lee K-F, Kucera J, Jaenisch R (1994) Lack of neurotrophin-3 leads to deficiencies in the peripheral nervous system and loss of limb proprioceptive afferents. Cell 77:503-512.

Ernsberger U, Degar D, Rohrer H (1989) The survival of early chick sympathetic neurons in vitro is dependent on a suitable substrate but independent of NGF. Dev Biol 135:250-262.

Fariñas I, Jones KR, Backus C, Wang XY, Reichardt LF (1994) Severe sensory and sympathetic deficits in mice lacking neurotrophin-3. Nature 36:658-661.

Gorin PD, Johnson EM (1980) Effects of long-term nerve growth factor deprivation on the nervous system of the adult rat: an experimental autoimmune approach. Brain Res 198:27-42. 
Hall AK, Landis SC (1991) Principal neurons and small intensely fluorescent (SIF) cells in the rat superior cervical ganglion have distinct developmental histories. J Neurosci 11:472-484.

Hall AK, Landis SC (1992) Division and migration of satellite glia in the embryonic rat superior cervical ganglion. J Neurocytol 21:635-647.

Hendry IA (1977) Cell division in the developing sympathetic nervous system. J Neurocytol 6:299-309.

Klein R, Smeyne RJ, Wrurst W, Long LK, Auerbach BA, Joyner AL, Barbacid M (1993) Targeted disruption of the trkB neurotrophin receptor gene results in nervous system lesion and neonatal death. Cell 75:1-20.

Klein R, Silos-Santiago I, Smeyne RJ, Lira SA, Brambilla R, Bryant S, Zhang L, Snider WD, Barbacid M (1994) Disruption of the neurotrophin-3 receptor gene trkC eliminates Ia muscle afferents and results in abnormal movements. Nature 368:249-251.

Korsching S (1993) The neurotrophic factor concept: a reexamination. J Neurosci 13:2739-2748.

Lamballe F, Tapley P, Barbacid M (1993) trkC encodes multiple neurotrophin-3 receptors with distinct biological properties and substrate specificities. EMBO J 12:3083-3094.

Levi-Montalcini R, Angeletti PU (1966) Immunosympathectomy. Pharmacol Rev 18:619-628.

Levi-Montalcini R, Booker B (1960) Destruction of the sympathetic ganglia in mammals by an antiserum to a nerve-growth protein. Proc Natl Acad Sci USA 46:384-391.

Rubin E (1985) Development of the rat superior cervical ganglion: ganglion cell maturation. J Neurosci 5:673-684.

Schecterson LC, Bothwell M (1992) Novel roles for neurotrophins are suggested by BDNF and NT-3 mRNA expression in developing neurons. Neuron 9:449-463.

Shibamori Y, Tamamaki N, Saito H, Nojyo Y (1994) The trajectory of the sympathetic nerve fibers to the rat cochlea as revealed by anterograde and retrograde WGA-HRP tracing. Brain Res 646:223-229.
Smeyne RJ, Klein R, Schnapp A, Long LK, Bryant S, Lewin A, Lira S, Barbacid M (1994) Severe sensory and sympathetic neuropathies in mice carrying a disrupted Trk/NGF receptor gene. Nature 368:246-249.

Snider WD (1994) Functions of the neurotrophins during nervous system development: what the knockouts are teaching us. Cell 77:627-638.

Tsoulfas P, Soppet D, Escandon E, Tessarollo L, Mendoza-Ramirez JL, Rosenthal A, Nikolics K, Parada LF (1993) The rat $t r k C$ locus encodes multiple neurogenic receptors that exhibit differential response to neurotrophin-3 in PC12 cells. Neuron 10:975-990.

Valenzuela DM, Maisonpierre PC, Glass DJ, Rojas E, Nunez L, Kong Y, Gies DR, Stitt TN, Ip NY, Yancopoulos GD (1993) Alternative forms of rat TrkC with different functional capabilities. Neuron 10:963-974.

Verdi JM, Anderson DJ (1994) Neurotrophins regulate sequential changes in neurotrophin receptor expression by sympathetic neuroblasts. Neuron 13:1359-1372.

Vogel KS (1994) Development of trophic interactions in the vertebrate peripheral nervous system. Mol Neurobiol 7:363-382.

Vogel KS, Davies AM (1991) The duration of neurotrophic factor independence in early sensory neurons is matched to the time course of target field innervation. Neuron 7:819-830.

White FA, Silos-Santiago I, Molliver DC, Nismimura M, Phillips H, Barbacid M, Snider WD (1996) Synchronous onset of NGF and TrkA survival dependence in developing dorsal root ganglia. J Neurosci 16:4662-4672.

Wyatt S, Davies AM (1993) Regulation of expression of mRNAs encoding the nerve growth factor receptors p75 and trkA in developing sensory neurons. Development 119:635-647.

Wyatt S, Davies AM (1995) Regulation of nerve growth factor gene expression in sympathetic neurons during development. J Cell Biol 130:1435-1446. 